TARNOWSKIE STUDIA TEOLOGICZNE 36 (2017) NR 2, S. 23-41

http://dx.doi.org/10.15633/tst.2613

ks. Tadeusz Pabjan ${ }^{1}$

UNIWERSYTET PAPIESKI JANA PAWŁA II W KRAKOWIE

\title{
Idea Bożej wszechmocy a problem zła
}

Jedno z najważniejszych zagadnień, które ma bezpośredni związek z problemem zła i które stawia pod znakiem zapytania dobroć Stwórcy, dotyczy tego, w jaki sposób należy interpretować ideę Bożej wszechmocy. Czy Bóg rzeczywiście może uczynić absolutnie wszystko, co tylko zechce? Czy nie istnieje żadne ograniczenie Jego wszechmocy? Odpowiedź na te pytania ma oczywiste konsekwencje dla problemu zła, i nic dziwnego, że analizy dotyczące tej kwestii pojawiają się raz po raz w argumentach formułowanych $\mathrm{w}$ ramach teodycei. $\mathrm{Z}$ całą pewnością jednym $\mathrm{z}$ bardziej istotnych ograniczeń Bożej wszechmocy jest wolność darowana człowiekowi: jeśli wolna wola ma być realną zdolnością do wybierania pomiędzy dobrem a złem, to znaczy że Bóg nie może zmusić człowieka do tego, by zawsze opowiadał się za dobrem i odrzucał zło. To ograniczenie Bożej wszechmocy może mieć jednak znacznie szerszy zasięg: jeśli bowiem Stwórca działa w stworzonym świecie za pośrednictwem praw przyrody, to nic nie stoi na przeszkodzie by przyjąć, że obdarza On wolnością nie tylko samego człowieka, ale również cały wszechświat, który w granicach określonych przez prawa przyrody może doświadczać autentycznej autonomii. Dzięki takiej interpretacji problem zła obecnego w stworzonym przez Boga świecie nabiera nowego, bardziej konkretnego sformułowania, które można łatwo skonfrontować z naukowym obrazem świata, i które w zasadniczy sposób rozszerza intuicję ukrytą $\mathrm{w}$ tradycyjnym pytaniu o to, dlaczego Bóg pozwala na zło.

Ks. Tadeusz Pabjan - doktor habilitowany, wykładowca filozofii przyrody i filozofii nauki na Wydziale Teologicznym Sekcja w Tarnowie UPJPII. 


\section{Czy Bóg rzeczywiście jest wszechmocny?}

Koncepcja Bożej wszechmocy nie ma prostej i jednoznacznej interpretacji. Wyjaśnienie oparte na dosłownym rozumieniu słowa „wszechmoc” (Bóg wszechmocny to znaczy taki, który może uczynić wszystko, co tylko zechce) wydaje się oczywiste, ale nawet pobieżna refleksja na tym zagadnieniem pozwala zauważać, w jak wielkim stopniu wyjaśnienie to upraszcza i zniekształca problem wszechmocy. Nic dziwnego, że w historii filozoficzno-teologicznych sporów interpretacja idei Bożej wszechmocy od samego początku była przedmiotem ożywionych i długotrwałych dyskusji, w których wskazywano, że koncepcja wszechmocy absolutnej - czyli takiej, której w ogóle nic nie ogranicza - jest wewnętrznie sprzeczna i z wielu względów nie da się jej utrzymać ${ }^{2}$ Oczywiście, zagadnienie to można rozpatrywać na wielu różnych płaszczyznach, a jego szczegółowe omówienie wymagałoby osobnego, obszernego opracowania. Aby ukazać całą złożoność tej problematyki, warto jednak w tym miejscu choćby krótko wspomnieć o kilku wybranych epizodach składających się na historię problemu Bożej wszechmocy.

We wczesnym chrześcijaństwie na interpretację tego zagadnienia istotny wpływ miały pojęcia filozofii greckiej, które pierwsi teologowie wykorzystywali do wyrażenia prawd wiary nowej religii. Biblijna idea Bożej wszechmocy nie miała jednak swojego odpowiednika w greckiej koncepcji bóstwa, która nakazywała pojmować boga w kategoriach kosmicznej zasady, gwarantującej stałość i niezmienność praw odpowiedzialnych za porządek świata. Z taką interpretacją kłóci się idea Boga, który troszcząc się o swoje stworzenie, może wkraczać w historię świata i w dowolny sposób zmieniać ustalone wcześniej reguły obowiązujące w przyrodzie. Świadectwem tego, jak bardzo takie rozumienie Bożej wszechmocy wydawało się obce umysłom przywykłym do myślenia w kategoriach antycznej filozofii, jest wypowiedź żyjącego w II wieku po Chrystusie rzymskiego lekarza Galena, który poddając krytyce przekonanie, iż „Bóg może wszystko”, dowodził, że „pewne rzeczy są niemożliwe z natury i Bóg nawet nie usiłuje uczynić takich rzeczy, ale wybiera najlepsze z tego, co jest możliwe, by

2 Por. np. M. Koszkało, M. Pepliński, Wszechmoc, w: Przewodnik po filozofii religii. Nurt analityczny, red. J. Salamon, Kraków 2016, s. 37-59; M. Pepliński, Problematyka wszechmocy Boga - rzeczy nowe i stare, „Filo-Sofija” 15 (2015) nr 30/3, s. 11-44. 
się stało"3. Tego typu spostrzeżenia autorów pozostających w kręgu kultury grecko-rzymskiej nie pozostawały bez wpływu na teologię ojców Kościoła, którzy podjęli systematyczną refleksję nad tym zagadnieniem.

Czy Bóg może uczynić wszystko, co tylko zechce? Pozytywna odpowiedź na to pytanie bardzo szybko uzupełniona została długą listą zastrzeżeń. Już Orygenes - za nim do podobnych pojęć odwoływał się św. Augustyn - zauważył, że istnieje zasadnicza różnica pomiędzy tym, co Bóg może uczynić w zasadzie (per potentiam), i tym, co czyni, kierując się racjonalnie uzasadnionymi przesłankami (ex iustitia). To rozróżnienie zostało w pismach późniejszych autorów doprecyzowane w następujący sposób: pierwszej możliwości (Stwórca „w zasadzie” może uczynić wszystko) odpowiada wszechmoc Boża absolutna (potentia absoluta), a drugiej (Stwórca czyni tylko to, co jest racjonalnie uzasadnione) - wszechmoc uporządkowana (potentia ordinata). Wszechmoc absolutna dotyczy zatem wszystkich możliwości, z których Bóg może wybierać, powołując do istnienia określone byty lub powodując pewne zdarzenia, a wszechmoc uporządkowana - tych możliwości, które Bóg faktycznie wybrał, i które znalazły swoją realizację w stworzonym świecie ${ }^{4}$.

W średniowieczu nie brakowało jednak teologów, którzy nie widzieli potrzeby ograniczania wszechmocy Boga tego typu subtelnymi rozróżnieniami. Tytułem przykładu: żyjący w xi wieku Piotr Damiani nie podzielał poglądów opata Dezyderiusza głoszącego, że Bóg nie może zmieniać zdarzeń przeszłych, które już miały miejsce; w jego własnej opinii Stwórca może zmieniać przeszłość, niejako „unieważniając” dokonane już zdarzenia i tworząc na nowo minioną historię świata ${ }^{5}$. Inni autorzy sprzeciwiali się jednak takim interpretacjom idei Bożej wszechmocy. Anzelm z Canterbury niemożność zmieniania tego, co już się dokonało, uzasadniał m.in. stałością i niezmien-

3 Galen, De usu partium, cyt. za: A. Funkenstein, Theology and the Scientific Imagination from the Middle Ages to Seventeenth Century, Princeton 1986, s. 125.

4 „Odróżnienie pomiędzy potentia Dei absoluta i potentia Dei ordinata stało się narzędziem teologiczno-filozoficznym, którego celem było przede wszystkim zagwarantowanie wolności samego Boga tak, aby mógł On wybierać z obszaru niezrealizowanych możliwości. Narzędzie to umożliwiło ówczesnym teologom i filozofom analityczne badanie różnych zagadnień, na przykład problemu stwarzania, problemu Inkarnacji, usprawiedliwienia i innych” (S. Judycki, Wszechmoc i istnienie, „Internetowe Czasopismo Filozoficzne Diametros” 21 (2008), s. 36).

Por. Damiani, O wszechmocy Bożej, tłum. I. Radziejowska, Warszawa 2010, rozdział 6, s. 67-71. 
nością woli Bożej, która nigdy nie cofa raz podjętych decyzji ${ }^{6}$. Możliwość dowolnego zmieniania przeszłości wydawała się również zagrażać logicznej spójności samej koncepcji Bożej wszechmocy, bo zmienianie zdarzeń, które już się dokonały, mogłoby prowadzić do sprzeczności. „Unieważniając” minioną historię, wszechmocny Stwórca mógłby nawet unicestwić siebie samego i swoją własną wszechmoc. Aby uniknąć takich paradoksów, należało przyjąć, że absolutna wszechmoc Boga musi mieć jednak wyraźne granice i nie może obejmować swoim zasięgiem rzeczy wewnętrznie sprzecznych, bo te - nawet dla wszechmocnego Boga - są absolutnie niemożliwe. Takie intuicje zamieniono wkrótce na powszechnie akceptowaną regułę, że Bożą wszechmoc ogranicza zasada niesprzeczności. To właśnie ta zasada decyduje o tym, że Bóg nie może stworzyć np. kwadratowego koła albo trójkąta o liczbie boków większej niż trzy. Wykluczenie wewnętrznej sprzeczności to podstawowy warunek wszechmocy uporządkowanej, która jest gwarancją ładu i harmonii dostrzeganej w stworzonym przez Boga świecie. Stwórca akceptuje obowiązujący w tym świecie porządek i sam go przestrzega, ponieważ jest on wyrazem Jego mądrości i dobroci.

Do rozróżnienia na wszechmoc absolutną i uporządkowaną w wielu swoich dziełach odwoływał się również Tomasz z Akwinu, który za Augustynem powtarzał, że Bóg mógł pewne akty wykonywać „ze względu na swoją moc”, ale zarazem nie mógł „ze względu na swoją sprawiedliwość”. Pod określeniem „sprawiedliwość" (iustitia) nie należy jednak w tym przypadku rozumieć tego, co słowo to oznacza zazwyczaj w relacjach międzyludzkich; w języku Akwinaty „sprawiedliwość” to Boża wierność względem stworzonego porządku świata. To właśnie ta wierność nakłada jedno z dwóch istotnych ograniczeń na absolutną wszechmoc Boga: Stwórca jest „wierny” ustalonym zasadom i prawom, które określają porządek panujący w świecie przyrody, i ze względu na tę wierność nie może tego porządku naruszać. Drugie ograniczenie wszechmocy wyznacza zasada niesprzeczności: Stwórca może czynić wszystko z wyjątkiem tego, co jest sprzecznością, bo byt, który realizowałby w sobie sprzeczność (pojmowaną w sensie formalno-logicznym) jest w rzeczywistości niebytem i dlatego nie może być stworzony przez Boga. Sprzeczność zatem „wyłącza się spod wszechmocy Bożej nie z powodu słabości potęgi Bożej, ale po prostu dlatego, że nie może mieć

6 Por. Anzelm z Canterbury, Monologion. Proslogion, tłum. T. Włodarczyk, Warszawa 1992, rozdział 7, s. 149-150. 
charakteru czegoś wykonalnego i możliwego"'. Wszechmoc Stwórcy jest również ograniczona przez to, że wyklucza ona z góry wszelkie działania niezgodne z Bożą wolą, która z konieczności zawsze chce dobra. Ograniczenia te nie są zbyt restrykcyjne i pozostawiają Bogu szeroki margines możliwości stwórczego działania. Wszechmoc uporządkowana polega zatem na tym, że Bóg dokonuje wyboru konkretnych skutków, których sam chce. To właśnie $\mathrm{z}$ tego powodu stworzony świat w rzeczywistości mógłby być inny niż jest: realizacja tej, a nie innej jego „wersji” wynika tylko i wyłącznie z wolnej decyzji Stwórcy.

Święty Tomasz był przekonany, że Bóg nie mógł stworzyć świata idealnego, w którym w ogóle nie byłoby zła. Jeśli jednak Stwórca miał możliwość wyboru, to czy mógł powołać do istnienia świat lepszy niż ten, który faktycznie stworzył? Zagadnieniem tym przed Tomaszem zajmował się m.in. Piotr Abelard, który uważał, że Bóg ze względu na swoją dobrą i mądrą naturę nie mógł stworzyć innego - a więc również lepszego - świata. Odmiennego zdania był Piotr Lombard głoszący, iż istotny jest określony aspekt działania Boga: działanie to odniesione do mądrości Stwórcy nie mogło być lepsze, w przeciwieństwie do działania odniesionego do samej rzeczy, bo to ostatnie mogło dać w rezultacie świat inny i lepiej uczyniony niż ten, który faktycznie zaistniał. Stanowisko św. Tomasza dotyczące możliwości stworzenia lepszego świata również opierało się na kilku subtelnych rozróżnieniach. Bóg mógł stworzyć świat składający się z lepszych bytów - w tym sensie, że akcydentalne (czyli nienależące do istoty) cechy tych bytów mogłyby być lepsze. Stworzone byty nie mogą być jednak lepsze ze względu na swą istotę, bo jakakolwiek próba „poprawienia” istoty danego bytu prowadziłaby w rzeczywistości do zmiany tej istoty, czyli do powstania nowego bytu. Jeśli zaś uwzględnić sposób działania Boga, który powołuje byty do istnienia, to Jego stwórcze działanie nie może być lepsze, niż jest: „Bóg nie może czynić lepiej, niż czyni; nie może przecież czynić z jeszcze większą mądrością i dobrocią"

Czy zatem oznacza to, że Bóg nie mógł stworzyć lepszego świata, że mając do dyspozycji zbiór wszystkich możliwych światów, wybrał najlepszą opcję, wedle której powołał go do istnienia? Odpowiedź Tomasza na te pytania nie

7 Św. Tomasz, Suma teologiczna, tłum. P. Bełch, t. 2, Londyn 1977, zagadnienie 25, artykuł 3, s. 89 .

${ }^{8}$ Św. Tomasz, Suma teologiczna, zagadnienie 25, artykuł 6, s. 93. 
jest jednoznaczna: „Wszechświat nie może być lepszy, jeśli się patrzy na poszczególne rzeczy jako stanowiące go. Przecież dobro wszechświata polega właśnie na tym cudownym zharmonizowaniu i ładzie, w jaki Bóg ujął wszystkie te rzeczy. Pomyślmy: Gdyby choć jedna z nich nagle stała się lepszą, uległaby zakłóceniu równowaga porządku panującego w świecie; tak jak psuje się cała gra cytry, jeśli choćby jedna struna jest naciągnięta więcej niż należy. Mógłby jednak Bóg czynić inne rzeczy lub dodawać inne do już uczynionych i tak wszechświat taki byłby lepszy" ". Jak widać, Akwinata nie daje jednej prostej odpowiedzi na pytanie o to, czy świat stworzony przez Boga rzeczywiście jest światem najlepszym z możliwych. Na uwagę zasługuje jednak jego trafne spostrzeżenie dotyczące wzajemnej zależności zachodzącej pomiędzy bytami w każdym z możliwych światów. Poszczególne „rzeczy” tworzące każdy z tych światów są z sobą w sposób harmonijny powiązane różnymi relacjami, i zmiana jednej z nich - choćby nawet miała ona polegać na jej „ulepszeniu” - mogłaby doprowadzić nie tylko do zakłócenia subtelnej równowagi całości, ale nawet do pojawienia się sprzeczności. To zaś z racji już wcześniej wspomnianych byłoby wykluczone z zakresu działań możliwych dla Bożej wszechmocy.

\section{Boża wszechmoc a prawa przyrody}

W teologicznej dyskusji nad problemem Bożej wszechmocny przez długi czas istotną rolę odgrywały argumenty filozoficzne ukazujące Stwórcę, który działa w świecie za pośrednictwem natury, czyli istoty rzeczy. Autorytet św. Tomasza, a także innych średniowiecznych teologów, sprawił, że w dyskusji tej cały czas uwzględniano rozróżnienie na przyczynę pierwszą - jest nią Bóg, będący bytem samoistnym, który uzdalnia wszystkie inne byty do istnienia - oraz przyczyny wtórne, które istnieją i działają mocą przyczyny pierwszej. Na początku czasów nowożytnych argumenty te zaczęły stopniowo zmieniać swój charakter ze względu na stopniowy rozwój refleksji metodologicznej, która towarzyszyła rodzącym się naukom empirycznym. Uświęcone tradycją pojęcie "natura” zostało niepostrzeżenie zastąpione określeniem „przyroda”, które już nie miało filozoficznych konotacji, nakazujących doszukiwania się w każdej rzeczy jej metafizycznej „istoty”. Zaczęto w związku z tą zmianą inaczej postrzegać działanie Boga w stworzonym świecie, i inaczej interpretować ograniczenia Jego wszechmocy.

9 Św. Tomasz, Suma teologiczna, zagadnienie 25, artykuł 6, s. 93. 
O ile wcześniej Stwórca działał poprzez prawa natury i był ograniczony metafizycznie pojmowaną istotą rzeczy, o tyle teraz Jego działanie dokonywało się za pośrednictwem praw przyrody. Prawa te można rozumieć jako swego rodzaju ograniczenia nałożone na działania przyrody, która „nie może” zachowywać się inaczej niż zgodnie z regułami określonymi przez te prawa. Z czasem zaczęto odkrywać, że prawa można wyrazić w języku matematyki, która nadaje się dobrze do tego, by precyzyjnie opisać „dozwolone” i „niedozwolone” zachowania przyrody. Stało się jasne, że ponieważ Bóg działa za pośrednictwem właśnie takich praw, dyskusja nad ewentualnymi ograniczeniami Bożej wszechmocy powinna rozpocząć się od ustalenia tego, co przyrodzie wolno, a czego nie wolno ${ }^{10}$.

Na początkowym etapie odkrywania tego, czym są prawa przyrody i w jaki sposób należy w nich odkrywać działanie Boga, dały o sobie znać dwie przeciwne tendencje. Pierwsza $z$ nich to racjonalizm, który ograniczał wszechmoc Stwórcy apriorycznymi zasadami i nie był skłonny do uwzględniania w systemie świata nadzwyczajnych interwencji Boga, naruszających integralność praw przyrody. Druga, przeciwna tendencja, to woluntaryzm, który postulował całkowite zniesienie wszelkich ograniczeń Bożej wszechmocy i wszystko uzależniał od wolnej decyzji (od „woli”) Stwórcy. Co ciekawe, obydwie tendencje przyczyniły się w istotnym stopniu do rozwoju nowożytnych nauk empirycznych. Racjonalizm - ponieważ głosił, że Bóg działa zawsze w przyrodzie w sposób przewidywalny, uporządkowany, matematyczny, i dlatego wystarczy znaleźć odpowiednie formuły (wyrażone wzorami matematycznymi), by poprawnie opisywać wszystkie zjawiska przyrodnicze. Woluntaryzm - ponieważ głosił coś dokładnie przeciwnego: że Bóg stwarzający świat przyrody kieruje się jedynie własną wolą i nie jest ograniczony żadnymi prawami, i dlatego jedyną skuteczną metodą poznania tego świata nie jest dedukowanie własności przyrody z jakichś apriorycznych zasad, ale empiryczne badanie tego, jak faktycznie wygląda świat stworzony przez Boga ${ }^{11}$.

${ }^{10} \mathrm{Na}$ ten temat por. M. Heller, Ostateczne wyjaśnienia wszechświata, Kraków 2006, rozdział 16, s. 177-183.

${ }^{11}$ Hooykaas dowodzi, że powstanie nauk przyrodniczych było możliwe dzięki tendencjom wolunatrystycznym. Por. R. Hooykaas, Religia i powstanie nowożytnej nauki, tłum. S. Ławicki, Warszawa 1975, s. 55-67. 
Czy zatem wszechmoc Stwórcy jest ograniczona przez prawa przyrody, a jeśli tak, to $\mathrm{w}$ jakim zakresie? Poszukiwanie odpowiedzi na to pytanie przez długi czas naznaczone było wyraźnym napięciem pomiędzy tezą o przygodności świata, którego struktura jest uzależniona od arbitralnych decyzji Boga i jako taka musi być mozolnie odkrywana przy zastosowaniu metody empirycznej, i tezą o racjonalności i uporządkowaniu przyrody, której strukturę Stwórca określił za pomocą matematycznych praw przyrody. Wielu twórców nowożytnej metody matematyczno-empirycznej oscyluje pomiędzy tymi dwoma możliwościami. Z upływem czasu przybywa jednak coraz więcej argumentów za tym, że przygodność świata przyrody nie może być interpretowana $w$ kategoriach zupełnie dowolnych - sprzecznych z prawami przyrody - decyzji Boga, który w całkowicie arbitralny sposób interweniuje w historię stworzonego świata. Owszem, obserwacje i eksperymenty muszą być elementem metody naukowej, ale konieczność ich uwzględnienia nie wynika $z$ tego, że przyroda zachowuje się w sposób nieprzewidywalny, bo decyzje Boga są kapryśne, ale $\mathrm{z}$ tego, że matematycznej struktury świata przyrody nie można wydedukować z apriorycznych zasad - do jej poprawnego odczytania konieczne jest doświadczalne badanie zjawisk. Przykładem uczonego, który w swojej pracy kieruje się właśnie taką metodologią, jest Kepler. Jego przekonanie o geometrycznej doskonałości świata, która jest określona przez kształty najbardziej symetryczne - kulę i okrąg - zostało zweryfikowane pod wpływem obserwacji ruchu Marsa i innych planet Układu Słonecznego. Okazało się, że orbity planet nie są koliste, ale eliptyczne ${ }^{12}$. To odkrycie nie było jednak dla Keplera dowodem na to, że Bóg w sposób całkowicie arbitralny zmienia ustalone wcześniej reguły rządzące światem przyrody; był to jedynie mocny argument za tym, że Stwórca „projektuje matematycznie”, posługując się bardziej subtelną matematyką niż ta, która opisuje jedynie kształty doskonale symetryczne ${ }^{13}$.

$\mathrm{Na}$ interpretację problemu Bożej wszechmocy duży wpływ miały w tym okresie poglądy Kartezjusza ${ }^{14}$, który w przedziwny sposób łączył ze sobą dwie wspomniane uprzednio, przeciwne tendencje: był jednym $\mathrm{z}$ najbardziej

${ }_{12}$ Na ten temat por. M. Heller, Uchwycić przemijanie, Kraków 1997, s. 125-132.

${ }^{13}$ W jednym ze swoich dzieł Kepler pisał: „rzeczy matematyczne są przyczynami rzeczy fizycznych, ponieważ na początku czasów Bóg powziął prosty, ale abstrakcyjny, plan rzeczy matematycznych, jako prototypów wielkości zaprojektowanych materialnie" (cyt. za: M. Heller, Ostateczne wyjaśnienia wszechświata, s. 182).

${ }^{14}$ Por. Z. Janowski, Teodycea kartezjańska, Kraków 1998, s. 117-161. 
przekonanych orędowników racjonalizmu, ale jednocześnie wyznawał skrajny woluntaryzm - opowiadał się za tym, że nawet twierdzenia matematyki zależą od woli Boga, który może w dowolny sposób zmieniać reguły leżące u podstaw tej dyscypliny. Paradoksalność tego poglądu wynika stąd, że jego wyznawcą był twórca geometrii analitycznej, który dyscyplinę tę uważał za wzór racjonalności określający w pewien sposób samą ontologię świata przyrody $^{15}$. Nic dziwnego, że „skrajność” kartezjańskiego woluntaryzmu w rzeczywistości jest pozorna - w tym sensie, że uzależnienie prawd matematyki od woli Boga jest tu czysto teoretycznym postulatem: Bóg - gdyby tylko zechciał - mógłby zmienić nawet twierdzenia matematyki, ale jednak z pewnych względów tego nie chce i w stworzonym przez siebie świecie konsekwentnie respektuje racjonalny porządek określony przez prawa przyrody. To właśnie z tego powodu wszechmoc Boga teoretycznie nie jest niczym - nawet prawami matematyki - ograniczona (odwołując się do wspomnianej uprzednio terminologii, można powiedzieć, że jest to wszechmoc "absolutna”), ale w praktyce ujawniają się wyraźne ograniczenia tej wszechmocy (jest ona „uporządkowana”), ponieważ Bóg będący źródłem i gwarantem racjonalności nie może w sposób dowolny zmieniać ustalonych przez siebie reguł.

Klarowny przykład takiej argumentacji pojawia się w kilku różnych dziełach Kartezjusza. Analizując problem genezy świata, autor ten zauważa, że chociaż Bóg mógł stworzyć wszystkie organizmy żywe i struktury przyrody nieożywionej od razu $\mathrm{w}$ gotowej postaci ${ }^{16}$ - jest wszechmocny, więc taka forma kreacji nie stanowi dla Niego żadnego problemu - to jednak w rzeczywistości posługuje się On prawami przyrody, które powodują stopniowy rozwój organizmów i struktur nieożywionych wypełniających cały wszechświat. Co istotne, ewolucja świata przyrody jest w tej interpretacji autonomiczna - w tym sensie, że dokonuje się bez nadzwyczajnych interwencji

15 Por. A. Funkenstein, Theology and the Scientific Imagination..., s. 179-192.

${ }^{16}$ W tekście Zasad filozofii znajdują się sformułowania sugerujące, że Kartezjusz jest całkowicie przekonany o tym, iż stworzenie należy rozumieć właśnie w taki sposób. Por. np. „Nie ulega wątpliwości, że świat od początku został stworzony z całą swą doskonałością tak, iż istniały w nim i słońce, i ziemia, i księżyc, i gwiazdy" (R. Descartes, Zasady filozofii, tłum. I. Dąbska, Warszawa 1960, II, 45, s. 121). McMullin dowodzi jednak, że Kartezjusz chciał w ten sposób jedynie zabezpieczyć się przed ewentualnym zarzutem braku ortodoksji, który niewiele wcześniej postawiono Galileuszowi. Por. E. McMullin, Ewolucja i stworzenie, tłum. J. Rodzeń, Kraków 1993, s. 42-46. 
Boga, który nie wpływa bezpośrednio na przebieg zdarzeń w stworzonym świecie. W swoim wyjaśnieniu Kartezjusz koncentruje się nie tyle na procesach biologicznej ewolucji życia, ile na rozwoju struktur kosmicznych (takich jak gwiazdy i planety) składających się na cały wszechświat. Jego celem jest wykazanie, że struktury te mogły rozwijać się stopniowo z chaotycznej materii stworzonej przez Boga u zarania dziejów i że taki rozwój doprowadziłby w konsekwencji do powstania obecnego świata. Stwórca nie musiałby ingerować $\mathrm{w}$ przebieg procesów przyrodniczych, ale „w dalszym ciągu współdziałałby z przyrodą na zwykły jedynie sposób, pozwalając jej działać wedle praw, które ustanowił" ${ }^{17}$. Kartezjusz wskazuje na trzy tego typu prawa ${ }^{18}$, podkreślając, że wynikają one wprost z niezmienności Boga, „który działając zawsze w taki sam sposób, osiąga zawsze takie same skutki”" Opierając się na tych prawach oraz na „wiecznych prawdach matematyki [...] zgodnie z którymi sam Bóg uczy nas, w jaki sposób rozmieścił wszystkie rzeczy według liczby, wagi i miary” ${ }^{20}$, można a priori dowieść, jakie obiekty powstaną w wyniku tego typu naturalnej ewolucji materii. Aby jednak rozumowanie to było poprawne, należy założyć, że Bóg w żaden nadprzyrodzony sposób nie naruszy autonomii i integralności tego procesu. Słuszność tego założenia Kartezjusz uzasadnia przywołanym uprzednio argumentem dotyczącym praw przyrody: „doskonałość Boga nie tylko na tym polega, że On sam w sobie jest niezmienny, ale i na tym, że działa w sposób jak najbardziej stały i niezmienny"

Jak widać, wszechmoc Boga nie jest w ujęciu Kartezjusza wszechmocą absolutną, ale uporządkowaną. Jej ograniczenie jest tu wyraźnie określone i zarazem uzasadnione - niezmiennym charakterem praw, przy pomocy których Stwórca kieruje światem przyrody. Z całą pewnością na kształt takiej interpretacji tego, jak należy pojmować Bożą wszechmoc, wpłynęło to, że dla Kartezjusza świat przyrody był jednym wielkim mechanizmem, którego

${ }_{17}$ R. Descartes, Rozprawa o metodzie, tłum. W. Wojciechowska, Warszawa 1988, s. 51.

${ }^{18}$ Ujmują one w sposób intuicyjny to, co później precyzyjnie zostanie wyrażone w trzech zasadach dynamiki Newtona.

${ }^{19}$ R. Descartes, Świat albo traktat o świetle, cyt. za: E. McMullin, Ewolucja i stworzenie, S. 40 .

${ }^{20}$ R. Descartes, Świat albo traktat o świetle, cyt. za: E. McMullin, Ewolucja i stworzenie, S. 40 .

${ }^{21}$ R. Descartes, Świat albo traktat o świetle, cyt. za: E. McMullin, Ewolucja i stworzenie, S. 40 . 
działanie można w pełni opisać i wyjaśnić, odwołując się do matematycznych praw przyrody. W takim ujęciu nadzwyczajne ingerencje „z zewnątrz”, które naruszają spójność tego mechanizmu, musiały się wydawać wyjątkowo nieodpowiednim sposobem działania dla wszechmocnego Boga. Wyjaśnienie mechanicystyczne niejako z założenia miało się odnosić do wszystkich obiektów wchodzących w skład świata przyrody, a więc miało również obejmować organizmy żywe. Kartezjusz sądził zatem, że nie tylko astronomiczne układy ciał niebieskich, ale również biologiczne ciała zwierząt działają jak systemy czysto mechaniczne. Podjął nawet próbę wyjaśnienia - analogiczną do tej, która opisywała stopniowy rozwój kosmosu - w jaki sposób i pod wpływem jakich przyczyn formowały się ciała zwierzą $t^{22}$. Nie była to jeszcze żadna „teoria” ewolucji biologicznej, a jedynie zbiór intuicji dotyczących tego, że organizmy żywe nie zostały przez Boga stworzone od razu w gotowej postaci, ale rozwijały się stopniowo w sposób ewolucyjny.

Nie są w tym przypadku istotne szczegóły wyjaśnień Kartezjusza ${ }^{23}$. Ważne jest to, że obydwie wspomniane hipotezy - dotyczące powstania wszechświata i stopniowego kształtowania się ciał zwierząt - oparte były na założeniu, iż każdy rodzaj struktury należącej do świata przyrody można wyjaśnić w sposób naturalny, poprzez odwołanie się do praw przyrody powodujących stopniowy rozwój tych struktur, a nie do nadzwyczajnych ingerencji Boga. Nie wszystkich czytelników dzieł Kartezjusza przekonały jego argumenty przemawiające za tym, że warto opowiedzieć się za koncepcją Stwórcy, który działa $\mathrm{w}$ świecie za pośrednictwem praw przyrody i nigdy tych praw nie narusza, bo to sprzeciwiałoby się Jego niezmiennej naturze. Wielu z nich uznało, że taka interpretacja to niedopuszczalne ograniczenie wszechmocy Boga, które wyklucza możliwość działania opatrzności. W ten oto sposób filozofia Kartezjusza dostarczyła motywacji do pracy zwolennikom koncepcji głoszącej, że Bóg działa w stworzonym świecie bezpośrednio, a nie poprzez prawa przyrody. Wkrótce przypomnieli oni i na nowo sformułowali jeden ze starych i dobrze znanych argumentów przemawiających za właśnie takim rozumieniem Bożego działania. Tak zwany argument z projektu

${ }^{22}$ Kartezjusz wspomina o tym zagadnieniu w Rozprawie o metodzie i $w$ Zasadach filozofii, i poświęca mu osobną rozprawę z roku 1648 zatytułowaną Opis ciała ludzkiego.

${ }^{23}$ Kartezjańską koncepcję Bożej wszechmocy oraz liczne argumenty tego autora z zakresu teodycei obszernie omawia Zbigniew Janowski w książce Teodycea Kartezjańska (Kraków 1998). 
do dziś rozwijany jest przez filozofów i teologów usiłujących znaleźć namacalny dowód na bezpośrednie działania Boga w przyrodzie. Oparta na nim apologetyka jest jednak wyjątkowo krótkowzroczna, bo zdaje się nie dostrzegać tego, że dowodząc istnienia Projektanta, w rzeczywistości zrzuca na Niego odpowiedzialność za wszystkie postaci cierpienia wynikającego z działania praw biologicznej ewolucji.

\section{Nieinterwencjonistyczne działanie Boga w przyrodzie}

Teologiczno-filozoficzny spór o wszechmoc Bożą nie zakończył się na Kartezjuszu - dyskusja nad tym zagadnieniem trwa nieprzerwanie do dzisiaj. W tym miejscu jednak nie jest potrzebne omawianie dalszych epizodów tego sporu, który w rzeczywistości sprowadza się do wymiany czysto teoretycznych argumentów dotyczących tego, co Bóg może i czego nie może. Dla głównego problemu teodycei istotne jest to, że cierpienia i wszystkich innych przejawów zła fizycznego nie da się pogodzić z ideą Boga, który może w każdej chwili interweniować w stworzonym przez siebie świecie, zawieszając i w dowolny sposób modyfikując prawa przyrody. Cierpienie jest brutalnym faktem, któremu nie można zaprzeczyć. Takim samym - tak samo realnym - faktem są trzęsienia ziemi, powodzie, choroby genetyczne i wszystkie inne postaci zła fizycznego, które kładą się cieniem na idei dobrego Boga. Wobec tego faktu wyjaśnienie głoszące, że Stwórca „w każdym momencie może interweniować", by ratować od cierpienia swoje stworzenie, jest całkowicie bezużyteczne. Jeśli zaś chodzi o tych, którzy bezpośrednio są zainteresowani wyjaśnieniem tej kwestii - tych, którzy sami doświadczają zła - to wyjaśnienie takie nie tylko nie pomaga, ale wręcz przeciwnie, jeszcze bardziej intensyfikuje ich cierpienie: sama świadomość tego, że Bóg bez żadnego problemu może od cierpienia ratować, ale jednak z jakichś bliżej nieokreślonych względów tego nie robi, bardzo często jest źródłem największej udręki. W tym kontekście staje się jasne to, dlaczego poszukując odpowiedzi na pytanie o problem zła, warto skoncentrować się na argumentach przemawiających za słusznością koncepcji, którą określa się niekiedy mianem nieinterwencjonistycznego modelu działania Boga ${ }^{24}$. Jest to wy-

\footnotetext{
${ }^{24} \mathrm{Na}$ temat tego modelu zob. np. D. Edwards, Jak działa Bóg?, tłum. M. Chojnacki, Kraków 2013, passim; T. Pabjan, Anatomia konfliktu. Pomiędzy nowym ateizmem a teologia nauki, Kraków 1016, rozdziały 5 i 6 , s. 115-169.
} 
jaśnienie, w którym zakłada się, że działanie Boga w stworzonym świecie nigdy nie narusza porządku określonego przez prawa przyrody, ale zawsze jest zgodne z tym porządkiem. W tym ujęciu Stwórca konsekwentnie respektuje integralność i autonomię tych praw, ponieważ są one Jego darem, który umożliwia stopniowy rozwój stworzonego świata, dokonujący się na różnych poziomach uorganizowania materii. Nie przez przypadek najważniejsze argumenty, które mają za zadanie obronić Boga przed zarzutem zła obecnego $\mathrm{w}$ stworzonym świecie, są zarazem argumentami przemawiającymi za słusznością tego modelu: jeśli bowiem Stwórca ma jakiś ważny powód ku temu, by Jego działanie nie było interwencją naruszającą prawa przyrody, ale konsekwentnie respektowało wynikający z nich porządek, to odpowiedzialność za zło fizyczne związane z działaniem tych praw z oczywistych względów będzie już miała zupełnie inny charakter niż wtedy, gdy zakłada się, że to sam Bóg jest bezpośrednią przyczyną takiego czy innego zła. Wiele wskazuje na to, że nie da się obronić Boga przed zarzutem zła inaczej, jak tylko zakładając, że Jego działanie w świecie przyrody ma zawsze charakter nieinterwencjonistyczny.

Uzasadniając słuszność tej koncepcji, wskazuje się najpierw na teologiczną prawdę o immanencji Boga, który od samego początku jest obecny w stworzonym świecie. Aktu stworzenia nie należy bowiem rozumieć jako jednorazowej i definitywnie zakończonej „czynności” Boga, który w pierwszym momencie historii świata powołał do istnienia to, co przed tym momentem nie istniało. Stworzenie dokonuje się nieustannie, ponieważ jest to akt rozciągnięty w czasie na cały okres istnienia tego, co stworzone. Za słusznością takiej interpretacji - określanej mianem koncepcji ciągłego stwarzania (creatio continua) - w przeszłości opowiadali się m.in. św. Augustyn i św. Tomasz z Akwinu, a obecnie stanowi ona integralną część teologicznej doktryny o stworzeniu, akceptowaną przez wszystkich teologów ${ }^{25}$. Skoro Bóg jest immanentnie obecny w stworzonym świecie, to znaczy, że Jego działanie nie może być rozumiane jako zewnętrzna interwencja, dzięki której Stwórca staje się obecny tam, gdzie wcześniej Go nie było. Bóg nie musi się wdzierać z zewnątrz do stworzonego świata, bo od pierwszego

25 „Po stworzeniu Bóg nie pozostawia stworzenia samemu sobie. Nie tylko daje mu byt i istnienie, ale w każdej chwili podtrzymuje je w istnieniu, pozwala mu działać i prowadzi je do jego celu” (Katechizm Kościoła Katolickiego, Poznań 1994, nr 301, s. 80). 
momentu jego zaistnienia ${ }^{26}$ jest w nim nieustannie obecny. To właśnie na ten aspekt natury Boga zwraca uwagę św. Paweł, który zauważa, że „w rzeczywistości jest On niedaleko od każdego z nas. Bo w nim żyjemy, poruszamy się i jesteśmy" (Dz 17, 27-28) $)^{27}$. Słuszność tej intuicji potwierdzają również argumenty Akwinaty dotyczące tego, że Bóg działa zawsze za pośrednictwem przyczyn wtórnych, które należą do świata przyrody. Stwórca jest ciągle obecny w stworzonych bytach i jako przyczyna pierwsza udziela im istnienia i uzdalnia do działania.

Nieustanna, stwórcza obecność Boga w świecie przyrody jest najgłębszym i najważniejszym uzasadnieniem tego, że Stwórca nie musi konkurować z prawami przyrody, które decydują o przebiegu procesów fizycznych; nie musi ich zawieszać ani naruszać, by uzyskać zamierzony przez siebie efekt. Procesy fizyczne bowiem to nic innego, jak ciągi naturalnych przyczyn i skutków - za Tomaszem można je określić mianem przyczyn wtórnych a to właśnie Bóg jako przyczyna pierwsza jest w nich nieustannie obecny, bo daje im istnienie i możność działania. W tej perspektywie staje się jasne to, że Stwórca nie ma najmniejszego powodu, by swymi działaniami naruszać prawa przyrody, które decydują o uporządkowanym i powtarzalnym przebiegu tych procesów. Dodatkowym argumentem, który może przemawiać za słusznością takiej interpretacji, jest to, że sama koncepcja praw przyrody nie jest jednoznaczna, i nie istnieją jasne kryteria decydujące o tym, że określone zjawisko można uznać za naruszenie danego prawa. Przez prawo przyrody zwykle rozumie się powtarzalną relację zachodzącą pomiędzy mierzalnymi zjawiskami przyrodniczymi. Ale czy sama powtarzalność wystarcza do tego, by jakaś relacja mogła być prawem przyrody? Albo czy brak powtarzalności i wyjątkowość relacji oznacza, że w danym przypadku można wykluczyć obecność jakiegoś prawa, bądź uznać, iż jakieś inne prawo nie zostało zachowane? Nie ma łatwych i niebudzących wątpliwości

${ }^{26} \mathrm{~W}$ sensie ścisłym istnienie stworzonego świata nie domaga się tego, by świat miał swój początek w czasie. Już św. Tomasz z Akwinu wykazał, że można sensownie mówić o stworzeniu świata istniejącego odwiecznie - świata, który nie ma swojego początku w czasie. Por. Św. Tomasz, O wieczności świata, w: Św. Tomasz z Akwinu, Dzieła wybrane, tłum. J. Salij, Warszawa 2001, s. 277-285.

${ }^{27}$ Koncepcja oparta na tej intuicji to tzw. panenteizm (greckie pan-en-theos oznacza dosłownie „wszystko w Bogu”). Na ten temat por. np. J. Życiński, Bóg i ewolucja, Podstawowe pytania ewolucjonizmu chrześcijańskiego, Lublin 2002, s. 132-136; P. Clayton, God and Contemporary Science, Edinburgh 1997, s. 233-240. 
odpowiedzi na te pytania. Pewnym rozwiązaniem tej trudności jest rozróżnienie - autorem takiej propozycji jest m.in. William Stoeger - praw przyrody znanych obecnie (są to prawidłowości, które do tej pory udało się odkryć) i jeszcze nieznanych (prawidłowości do tej pory nieodkryte, które opisują najgłębsze, podstawowe zasady funkcjonowania nieskończenie bogatej i wieloaspektowej rzeczywistości ${ }^{28}$. Nawet jeśli czasem działanie Boga wydaje się być interwencją naruszającą określone prawo przyrody, to takie naruszenie dotyczy jedynie praw w pierwszym, a nie w drugim znaczeniu. Obecnie znane prawa przyrody stanowią jedynie niewielki podzbiór praw fundamentalnych, które obejmują swoim zasięgiem również to, czego nie jest w stanie wyjaśnić współczesna nauka. Ma to oczywiste konsekwencje dla teologicznej interpretacji zdarzeń cudownych, które - właśnie z tej racji - nie powinny być pojmowane w kategoriach naruszenia praw przyrody, bo w dużej mierze kwestią umowną jest to, co w danym przypadku jest, a co nie jest prawem przyrody ${ }^{29}$.

$\mathrm{Z}$ wielu różnych argumentów o charakterze teologicznym, które przemawiają za słusznością nieinterwencjonistycznego modelu działania Boga, warto w tym miejscu przywołać jeszcze jedną - być może najważniejszą rację odwołującą się do fundamentalnej dla całej teologii prawdy o Bożej miłości wobec stworzenia. Prawda ta ma mocne podstawy biblijne - całe Objawienie jest w rzeczywistości przekazem Dobrej Nowiny o tym, że „Bóg umiłował świat” (J 3, 16); że „jest miłością" (1 J 4, 8), która jest „odwieczna” (Jr 31,3). Jeśli miłość Boga wobec stworzeń ma być autentyczna, to musi respektować wszystkie ograniczenia wynikające z ich natury i zarazem obdarzać je wolnością. Nie widać jednak żadnej racji, dla której kategoria wolności miałaby być zarezerwowana jedynie dla rozumnego człowieka, który ma zdolność do podejmowania wolnych decyzji i do niczym nieskrępowanego wybierania pomiędzy dobrem i złem. Wolność powinna również przysługiwać światu przyrody, który może rozwijać się w sposób

${ }^{28}$ Według Stoegera, mówiąc o prawach przyrody „możemy mieć na myśli prawidłowości, relacje, procesy i struktury istniejące w przyrodzie (1) tak, jak je znamy, rozumiemy i przedstawiamy za pomocą modeli, lub (2) tak, jak faktycznie funkcjonują w rzeczywistości o wiele, wiele bogatszej niż to, co wiemy, rozumiemy, czy to, co udało się nam adekwatnie odwzorować" (W. R. Stoeger, The Mind-Brain Problem, the Laws of Nature and Constitutive Relationships, w: Neuroscience and the Person: Scientific Perspectives on Divine Action, ed. R. J. Russell, N. C. Murphy, T. C. Meyering, M. A. Arbib, Vatican City State-Berkeley 1999, s. 130).

${ }^{29} \mathrm{Na}$ ten temat por. T. Pabjan, Anatomia konfliktu, s. 141-169. 
autonomiczny. Co istotne, pełna autonomia nie oznacza w tym przypadku dowolności prowadzącej do całkowitego chaosu, bo wszechświat stworzony przez Boga jest racjonalny i uporządkowany, a gwarantem tej racjonalności są właśnie prawa przyrody. Jednak w granicach wyznaczonych przez te prawa materia może ewoluować w sposób wolny i nieskrępowany. Owszem, wszechmocny Stwórca mógłby naruszyć porządek określony przez prawa przyrody, ale respektuje autonomię materii z tych samych powodów, dla których respektuje również ludzką wolność. Nie zmusza człowieka, by był Mu posłuszny i by zawsze wybierał dobro, a odrzucał zło, i dlatego również nie determinuje świata przyrody i nie domaga się tego, by w swoim rozwoju realizował on posłusznie ustalony przez Niego scenariusz zdarzeń.

Warto zauważyć, że jest to ciekawy argument, który wydaje się dostarczać trafnej odpowiedzi na pytanie o zło fizyczne, będące konsekwencją działania praw przyrody. Jeśli wolność rzeczywiście jest aż tak wielką wartością, że Bóg obdarza nią człowieka, choć wie, iż Jego dar może być źle wykorzystany (może prowadzić do grzechu, czyli zła moralnego), to nic dziwnego, że Stwórca podejmuje również analogiczne ryzyko w przypadku świata przyrody. Gwarantuje realną autonomię światu materii, wiedząc o tym, że ceną tej autonomii może być zło fizyczne wynikające $\mathrm{z}$ takich zjawisk jak trzęsienia ziemi, powodzie i inne kataklizmy. Intuicja ta wpisuje się wyjątkowo dobrze w teologiczną interpretację procesów ewolucyjnych, które nieustannie dokonują się we wszechświecie, o czym w następujący sposób pisze John Haught: „Bóg wiary chrześcijańskiej nie jest kimś, kto ogranicza świat i zmusza go do rozwijania się według ściśle ustalonego planu. Zamiast tego Bóg chce, aby świat «stał się sobą» tak dalece, jak to możliwe. Oznacza to, że świat musi mieć przestrzeń i czas, aby błądzić, próbując różnych możliwości. Chociaż Boski umysł jest źródłem wszystkich możliwych alternatywnych dróg, które wszechświat może obrać w swej przygodzie ewolucyjnej, to możemy swobodnie przyjąć, że Bóg miłości nie popchnie go, aby w milczeniu szedł z góry określoną drogą. Jeśli Bóg miłuje świat, to wolno nam sądzić, że zostawia mu pewien margines wolności, aby eksperymentował wśród wielu możliwości swojego rozwoju"30.

W nakreślonej perspektywie zupełnie inaczej wygląda prawda o Bożej opatrzności, której nie należy rozumieć w ten sposób, że cały świat z żelazną

$3^{\circ}$ J. F. Haught, Odpowiedzi na 101 pytań o Boga i ewolucję, tłum. J. Kochanowicz, Kraków 2003, s. 74 . 
konsekwencją zmierza do celu ustalonego przed wiekami przez Stwórcę, a wszystkie byty odgrywają posłusznie swoje role, określone w ustalonym przez Niego scenariuszu zdarzeń. Jeśli autonomia dana stworzeniom ma być autentyczna, to opatrzność musi polegać na czym innym: na tym, że Stwórca $\mathrm{z}$ troską i niepokojem towarzyszy światu, ale zarazem nie narusza danej mu wolności, respektując wszystkie konsekwencje i ograniczenia, które $\mathrm{z}$ tej wolności wynikają. To właśnie z tej racji opatrznościowa troska Boga o człowieka i wszystkie inne stworzenia nie może oznaczać nieustannej interwencji, która miałaby na celu wyeliminowanie cierpienia i wszystkich innych form zła fizycznego.

Czy można uznać, że główny problem teodycei zyskuje w takim wyjaśnieniu satysfakcjonujące rozwiązanie? Cierpienie niewinnych istot było, jest i zapewne na zawsze pozostanie tajemnicą, do której należy podchodzić $\mathrm{z}$ wiarą, a nie z zestawem zgrabnych argumentów, które mają jednoznacznie rozstrzygnąć to zagadnienie. Jednoznacznego rozstrzygnięcia nie ma, ale warto go poszukiwać i przybliżać się do niego, precyzując intuicje ukryte w teologicznej prawdzie mówiącej o Bożej wszechmocy. Nawet pobieżna analiza tej prawdy wskazuje, że wszechmoc Stwórcy musi podlegać wielorakim ograniczeniom, co z kolei domaga się radykalnej reinterpretacji prawdy o opatrznościowym działaniu Boga w świecie przyrody. Teologiczne konsekwencje takiej reinterpretacji są poważne, ale wszystko wskazuje na to, że tylko na tej drodze można poszukiwać wyjaśnienia problemu zła, które jawi się jako najmocniejszy argument przemawiający przeciwko dobremu Bogu.

\section{Bibliografia}

Anzelm z Canterbury, Monologion. Proslogion, tłum. T. Włodarczyk, Warszawa 1992. Clayton P., God and Contemporary Science, Edinburgh 1997.

Damiani, O wszechmocy Bożej, tłum. I. Radziejowska, Warszawa 2010.

Descartes R., Rozprawa o metodzie, tłum. W. Wojciechowska, Warszawa 1988.

Descartes R., Zasady filozofii, tłum. I. Dąbska, Warszawa 1960.

Edwards D., Jak działa Bóg?, tłum. M. Chojnacki, Kraków 2013.

Funkenstein A., Theology and the Scientific Imagination from the Middle Ages to Seventeenth Century, Princeton 1986.

Haught J. F., Odpowiedzi na 101 pytań o Boga i ewolucję, tłum. J. Kochanowicz, Kraków 2003. 
Heller M., Ostateczne wyjaśnienia wszechświata, Kraków 2006.

Heller M., Uchwycić przemijanie, Kraków 1997.

Hooykaas R., Religia i powstanie nowożytnej nauki, tłum. S. Ławicki, Warszawa 1975. Janowski Z., Teodycea kartezjańska, Kraków 1998.

Judycki S., Wszechmoc $i$ istnienie, „Internetowe Czasopismo Filozoficzne Diametros" 21 (2008), s. 30-62.

Koszkało M., Pepliński M., Wszechmoc, w: Przewodnik po filozofii religii. Nurt analityczny, red. J. Salamon, Kraków 2016, s. 37-59.

McMullin E., Ewolucja i stworzenie, tłum. J. Rodzeń, Kraków 1993.

Pabjan T., Anatomia konfliktu. Pomiędzy nowym ateizmem a teologia nauki, Kraków 2016.

Pepliński M., Problematyka wszechmocy Boga - rzeczy nowe i stare, „Filo-Sofija” 15 (2015) $\mathrm{nr} 30 / 3$, s. 11-44.

Stoeger W. R., The Mind-Brain Problem, the Laws of Nature and Constitutive Relationships, w: Neuroscience and the Person: Scientific Perspectives on Divine Action, ed. R. J. Russell et al., Vatican City State-Berkeley 1999.

Tomasz św., O wieczności świata, w: Św. Tomasz z Akwinu, Dzieła wybrane, tłum. J. Salij, Warszawa 2001, s. 277-285.

Tomasz św., Suma teologiczna, tłum. P. Bełch, Londyn 1977.

Życiński J., Bóg i ewolucja. Podstawowe pytania ewolucjonizmu chrześcijańskiego, Lublin 2002.

\section{Streszczenie}

Tematyka artykułu oscyluje wokół koncepcji Bożej wszechmocy postrzeganej przez pryzmat głównego problemu teodycei, która stara się znaleźć odpowiedź na pytanie, dlaczego Bóg pozwala na zło. Jeden $\mathrm{z}$ argumentów wykorzystywanych w ramach tej dyscypliny odnosi się do różnego rodzaju ograniczeń Bożej wszechmocy, które decydują o tym, że z pewnych względów wszechmocny Stwórca nie może zapobiec różnym formom zła. Takim ograniczeniem jest np. wolność darowana człowiekowi - pozwalając na istnienie wolnej woli Bóg nie może powstrzymać działań człowieka prowadzących do zła. W artykule poddano analizie nieco inny aspekt tego samego ograniczenia, który ma związek z funkcjonowaniem świata przyrody: Bóg daje wolność nie tylko rozumnemu człowiekowi, ale również całej materii, która w granicach wyznaczonych przez prawa przyrody może doświadczać autentycznej autonomii. W tej interpretacji zło fizyczne jawi się jako prosta konsekwencja 
integralności procesów przyrodniczych. Pierwsza część artykułu dotyczy samej idei Bożej wszechmocy; w drugiej części idea ta zostaje odniesiona do koncepcji praw przyrody; w trzeciej i ostatniej omówiony jest tzw. nieinterwencjonistyczny model działania Boga w przyrodzie.

\section{Słowa kluczowe}

Boża wszechmoc, problem zła, zło fizyczne, prawa przyrody

\section{Summary}

\section{The Idea of God's Omnipotence and the Problem of Evil}

This article deals with the relation between the theological idea of God's omnipotence and the problem of evil which refers to the question of how to reconcile the existence of evil with God who is good. One of the main arguments of theodicy, which is a philosophical discipline dealing with this question, points to some important limitations of God's omnipotence. According to this argument, God's power is limited by different factors. One of them is human freedom: God can not prevent evil resulting from free decisions of people, because He himself decided them to be free. But this argument can be extended to the whole created world: God gives freedom not only to man, but to the whole universe as well, and this is why it can freely evolve in the boundaries of laws of nature. Physical evil is a simple consequence of such freedom of created world. The paper is composed of three parts. At first, the very idea of God's omnipotence is discussed. Then the relation of God's omnipotence and the laws of nature is expounded. In the end the so called non-interventionist model of God's action in nature is presented.

\section{Keywords}

God's omnipotence, problem of evil, physical evil, laws of nature 